\title{
MENINGKATKAN MOTIVASI DAN HASIL BELAJAR MATA PELAJARAN KIMIA MELALUI PENGGUNAAN ANIMASI SEDERHANA DENGAN MODEL PEMBELAJARANKOOPERATIF TIPE SAVI PADA SISWA KELAS X MIA 1 SMA NEGERI 3 SUNGAI PENUH
}

\author{
Hafizar \\ SMA Negeri 3 Sungai Penuh \\ hafizar26hafiz@gmail.com
}

\begin{abstract}
ABSTRAK
Hasil belajar yang dicapai siswa pada tahun-tahun sebelumnya selalu dibawahKriteria Ketuntasan Minimal (KKM). Rendahnya hasil belajar siswa yang dicapaidapat disebabkan oleh motivasi siswa untuk belajar kimia masih rendah danproses pembelajaran atau sarana belajar yang kurang memadai. Salah satuupaya untuk meningkatkan motivasi dan hasil belajar yaitu denganmenggunakan Animasi Sederhana. Dengan menggunakan modelpembelajaran kooperatif tipe SAVI (adalah kependekan dari: Somatic yangbermakna gerakan tubuh (hands-on, aktivitas fisik) di mana belajar denganmengalami dan melakukan; Auditory yang bermakna bahwa belajar haruslahdengan melalui mendengarkan, menyimak, berbicara, presentasi, argumentasi,mengemukakan pendapat, dan menanggapi; Visualization yang bermaknabelajar haruslah menggunakan indra mata melalui mengamati, menggambar,mendemonstrasikan, membaca, menggunakan media dan alat peraga; danIntellectualy yang bermakna bahwa belajar haruslah menggunakankemampuan berpikir (minds-on) belajar haruslah dengan konsentrasi pikirandan berlatih menggunakannya melalui bernalar, menyelidiki, mengidentifikasi,menemukan, mencipta, mengkonstruksi, dan memecahkan masalah.Hal ini bertujuan untuk meningkatkan motivasi dan aktivitas siswa sehingga memudahkan siswa memahami konsep-konsep Kimia. Penelitian ini dilaksanakan dalam dua siklus, masing-masing siklus dilakukan 2 (dua) kali pertemuan. Pada siklus I menunjukan peningkatan prosentase aktivitas siswa, pada pertemuan pertama $30 \%$ dan pertemuan kedua $65 \%$. Sedangkan di siklus II pertemuan pertama $70 \%$ dan pertemuan kedua $85 \%$. Hasil belajarpun mengalami peningkatan di siklus I ketuntasan belajar $70 \%$, sedangkan disiklus II ketuntasan belajar $83 \%$, disamping itu tanggapan siswa juga positif terhadap model pembelajaran kooperatif tipe SAVI ini terlihat dari angket yang dijawab siswa yang merasa senang dengan model pembelajaran ini.
\end{abstract}

Kata Kunci: Motivasi, Hasil Belajar, Pembelajaran Kooperatif SAVI 


\section{PENDAHULUAN}

Dirasakan oleh para pendidik, banyak siswa yang kurang berminat pada pelajaran kimia. Ilmu kimia merupakan salah satu mata pelajaran yang sering dianggap sebagai pela-jaran yang sulit. Apabila anggapan tersebut terus melekat, maka akan berakibat pada penurunan hasil belajar. Padahal pada tahun Pelajaran 2016 / 2017 mata pelajaran kimia merupakan salah satu mata pelajaran yang diujikan secara nasional. Oleh karena itulah perlu adanya inovasi pembelajaran menggunakan metode dan pendekatan yang bervariasi agar lebih menarik dan mudah dimengerti.

Selama ini para siswa umumnya menerima pelajaran kimia dengan metode ceramah dan diskusi tanpa dikenalkan dengan model pembelajaran yang menggambarkan proses yang mendekati kenyataan yang sebenarnya. Bertolak dari sulitnya mengajarkan kimia khususnya pada topik-topik yang abstrak mendorong penulis untuk mencari alternatif cara mengajar kimia sehingga mampu menumbuhkan minat siswa untuk belajar kimia. Dengan timbulnya rasa senang belajar, diharapkan penguasaan siswa terhadap mata pelajaran kimia menjadi lebih baik. Pada akhirnya akan meningkatkan prestasi belajar siswa pada mata pelajaran kimia.

Pada topik-topik abstrak yang sulit dijelaskan dengan cara diskusi informasi di kelas dapat dijelaskan secara visualisasi melalui unjuk kerja, oleh sebab itu peneliti menggunakan program animasi sederhana, cara ini telah peneliti gunakan disekolah tempat peneliti bertugas. Hasil belajar menunjukkan peningkatan yang cukup signifikan.

Model pembelajaran kooperatif tipe SAVI merupakan salah satu model pembelajaran yang mendukung pembelajaran kontekstual. Pem-belajaran kooperatif tipe SAVI adalah salah satu bentuk pembelajaran yang berdasarkan faham konstruktivis.

Pembelajaran kooperatif tipe SAVI merupakan strategi belajar mengajar dengan mengutamakan gerakan tubuh (hands-on, aktivitas fisik) di mana 
belajar dengan menga-lami dan melakukan; Auditory yang bermakna bahwa belajar haruslah dengan melalui mendengarkan, menyimak, berbicara, presentasi, argumentasi, mengemukakan pendapat, dan menanggapi; Visualization yang bermakna belajar haruslah menggunakan indra mata melalui mengamati, menggambar, mendemons- trasikan, membaca, menggunakan media dan alat peraga; dan Intellectualy yang bermakna bahwa belajar haruslah menggunakan kemam-puan berpikir (minds-on) belajar haruslah dengan konsentrasi pikiran dan berlatih menggunakannya melalui bernalar, menyelidiki, mengidentifikasi, menemukan, mencipta, meng-konstruksi, dan memecahkan masalah.

Penerapan pembelajaran kooperatif tipe SAVI akan memberikan hasil yang efektif kalau animasi sederhana yang digunakan memadai untuk kegiatan siswa belajar.Langkah-langkah dalam model pembelajaran tipe SAVI adalah sebagai berikut :

1. Menyampaikan tujuan pembelajaran yang ingin dicapai

2. Guru menyajikan materi sebagaimana biasanya.

3. Siswa menggunakan perangkat disekitarnya (Animasi sederhana) secara berpasangan atau kelompok.

4. Untuk mengetahui daya serap siswa, dilakukan uji kompetensi pada akhir pela-jaran.

5. Guru mengulangi/ menjelaskan kembali materi yang sekiranya belum dipahami siswa

6. Kesimpulan/ penutup

\section{METODOLOGI PENELITIAN}

Penelitian ini merupakan penelitian tindakan kelas (PTK) atau dalam bahasa Inggris disebut Classroom Action Research ( CAR ). Penelitian ini dimaksudkan untuk meningkatkan motivasi belajar siswa dan hasil belajar siswa yang berkaitan dengan proses pembelajaran di kelas, khususnya pada 
pema-haman konsep senyawa karbon dengan menggunakan animasi sederhana dan metode pembelajaran kooperatif tipe SAVI.

Penelitian tindakan kelas ini dilaksanakan pada semester ganjil tahun pela-jaran 2016/2017 di kelas X MIA1 SMA Negeri 3 Sungai Penuh mulai dari bulan September sampai November sebanyak 4 kali pertemuan yang dibagi menjadi 2 siklus. Siklus I sebanyak 2 kali pertemuan dan siklus II sebanyak 2 kali pertemuan.

Prosedur penelitian tindakan kelas ini secara garis besar dapat dilihat dalam tabel berikut ini :

\section{Siklus I}

\section{Perencanaan}

1. Merencanakan pembelajaran yang akan diterapkan dilaksanakan.

2. Menentukan pokok bahasan

3. Mengembangkan rencana pelaksanaan pembelajaran (RPP).

4. Menyiapkan sumber belajar seperti buku

5. Mengembangkan format evaluasi

Tindakan

1. Melaksanakan KBM yang mengacu pada rencana pelaksanaan pembelajaran yang telah disiapkan.

2. Melakukan evaluasi dalam bentuk tes kemampuan pemahaman konsep yang dipelajari.

Pengamatan

Melakukan observasi dengan menggunakan format observasi

Refleksi

1. Melakukan evaluasi tindakan yang telah dilakukan meliputi efektifitas waktu yang telah dilaksanakan.

2. Membahas hasil tindakan.

3. Memperbaiki pelaksanaan tindakan yang telah dilakukan yang belum mencapai sasaran. 
4. Evaluasi tindakan.

\section{Siklus II}

\section{Perencanaan}

1. Identifikasi masalah dan penetapan alternatife pemecahan masalah

2. Pengembangan program tindakan II

Tindakan

Pelaksanaan program tindakan II

Pengamatan

Pengumpulan data tindakan II

Refleksi

Evaluasi tindakan II

Indikator keberhasilan siklusII

1. Instrument-instrumen yang telah disiapkan pada siklus II dapat terlaksanakan semua

2. Aktifitas siswa dalam KBM meningkat.

3. Motivasi siswa dalam KBM meningkat

4. Hampir $100 \%$ pencapaian hasil belajar menunjukan peningkatan.

Sumber data penelitian ini adalah siswa, sedangkan jenis data yang didapatkan dalam penelitian ini adalah data kuantitatif dan data kualitatif yang meliputi :

1. Data hasil pretes dan postes

2. Hasil observasi terhadap proses Kegiatan Belajar-Mengajar

3. Jawaban angket

4. Jurnal harian/ catatan lapangan

5. Foto kegiatan

Data obsevasidi ambil melalui pengamatan yang dilakukan oleh kolaborator sebagai observer, yang dilakukan pada saat berlangsungnya kegiatan pembelajaran di kelas. Pengolahannya dengan menggunakan rumus: 


\section{A/B X $100 \%$}

dimana $\mathrm{A}=$ Jumlah siswa yang melakukan kegiatan

$\mathrm{B}=$ Jumlah siswa keseluruhan

Menganalisis data hasil angket dengan menggunakan rumus sebagai berikut :

Jumlah responden actual

-

Jumlah seluruh responden

\section{HASIL PENELITIAN}

Penelitian ini berupaya untuk mengung-kapkan hasil implementasi dari proses pem-belajaran dengan model kooperatif learning tipe SAVI dalam rangka meningkatkan motivasi serta aktivitas siswa dan hasil belajar yang diperoleh siswa. Pelaksanaan penelitian ini dilakukan dengan dua siklus yaitu siklus I dan siklus II.

\section{Siklus I}

\section{Aktivitas Belajar}

Peneliti melakukan pengamatan diantara-nya kerjasama dalam kelompok, bertanya, dan kemampuan penguasaan alat peraga. Pada saat berlangsungnya kegiatan belajar di dalam kelas, Pada pertemuan pertama ini belum nampak adanya aktivitas siswa yang mencolok, namun siswa lebih cenderung untuk bertanya tentang cara melakukan animasi tersebut. Berdasar datahasil observasi, diperoleh 4 kelompok siswa (25\%) yang bekerjasama, 12 kelompok siswa (75 \%) yang bertanya, 4 kelompok siswa (25\%) yang menguasai cara melakukan animasi dan yang menjawab soal uji kompetensi diatas KKM sebanyak 2 kelompok siswa $(12,5 \%)$. Prosentase aktivitas belajar secara keseluruhan diperoleh sebesar $36 \%$. 
Data tersebut diperoleh melalui lembar observasi kegiatan siswa. Pada pertemuan kedua di siklus I yang dilaksanakan pada hari Senin tanggal 22 Oktober 2016 guru masih meminta siswa untuk menggunakan animasi sederhana yang dilaksanakan di dalam kelas. Aktivitas kelas pada pertemuan kedua ini sudah ada peningkatan dibandingkan pertemuan pertama.

8 kelompok siswa (50\%), bekerja sama, 9 kelompok siswa (56\%), aktivitas yang bertanya, 8 kelompok siswa (50\%), yang menguasai animasi tersebut. dan yang menjawab soal uji kompetensi diatas KKM sebanyak 6 kelompok siswa (37\%). Prosentase aktivitas kelas secara keseluruhanyaitu 68 \%. Dibandingkan dengan pertemuan pertama, sudah ada peningkatan aktivitas kelas sebesar $32 \%$.

\section{Hasil Belajar}

Hasil pretes I ternyata diperoleh skor nilai rata-rata 44,20 dan prosentase ketuntasan belajar sebesar $28 \%$ yaitu hanya 7 orang siswa yang sudah tuntas dari 25 siswa. Hal ini menunjukkan bahwa kemampuan pemahaman konsep ikatan pada senyawa karbon secara umum masih dibawah Kriteria Ketuntasan Minimal yang telah ditetapkan yaitu 62. Walaupun demikian skor nilai ini masih dianggap wajar, karena memang belum diajarkan (belum dilakukan proses pembelajaran di kelas).

Waktu yang digunakan untuk pretes I adalah 30 menit. Berdasarkan hasil pretes I yang diperoleh, yaitu ketuntasan belajar hanya $28 \%$, maka dapat dijadikan dasar pertimbangan dalam melakukan suatu upaya untuk mening-katkan pemahaman konsep senyawa karbon dengan menggunakan model pembelajaran kooperatif tipe SAVI.

Setelah proses pembelajaran yang berlangsung di siklus I, sebanyak 2 kali per-temuan maka untuk mengetahui adanya peningkatan hasil belajar setelah diberi tindakan, siswa diberikan postes I yang dilaksanakan hari Senin tanggal 22 Oktober 2016. Berdasarkan hasil dari postes I diperoleh skor nilai rata-rata 
64,60 dan prosentase ketuntasan belajar mencapai $76 \%$, yaitu sebanyak 19 siswa yang sudah tuntas, dan hanya 6 orang siswa yang belum tuntas

\section{Refleksi}

Ternyata penerapan pembelajaran dengan menggunakan model pembelajaran kooperatif tipe SAVI konsep senyawa karbon memberikan hasil yang cukup memuaskan sesuai dengan target yang diharapkan. Hal ini dapat di-katakan adanya peningkatan prosentase aktivitas kelas.

Secara keseluruhan aktivitas belajar di siklus I meningkat dari $36 \%$ menjadi 68\%. Dalam hal ini aktivitas kelas sudah termasuk kategori aktif, karena kriteria keaktifan kelas dikatakan cukup apabila proses aktivitas kelasberkisar antara $50-75 \%$.

Beberapa jenis aktivitas siswa yang masih dianggap rendah, yaitu aktivitas dalam hal penguasaan teknik animasi sederhana. Diperkirakan bahwa siswa masih belum menguasai betul materi pelajaran yang sedang dibahas, sehingga berpengaruh terhadap hasil postes yang dilakukan pada akhir pelajaran. Rendahnya penguasaan teknik animasi kimia tersebut membuat peneliti harus bekerja keras kembali menjelaskan langkah-langkah membuat animasi tersebut. Oleh karena itu nampaknya perlu ada pendekatan guru terhadap siswa untuk bisa merangsang atau menumbuhkan rasa percaya diri bagi siswa dengan cara belajar yang maksimal dan menjelaskan bahwa hal ini masih sedang taraf belajar. Siswa juga perlu dilatih keberanian mentalnya untuk mau mencoba aktif dalam hal mengemukakan pendapat, ataupun ada keberanian menyanggah, apabila hal itu tidak sesuai dengan konsep yang dia yakini (misalkan dari buku sumber).

Adapun hasil belajar yang diperoleh melalui postes I, setelah berakhirnya pem-belajaran pada pertemuan di siklus I, diperoleh skor nilai rata-rata kelas sebesar 64,60 dengan prosentase ketuntasan belajar sebesar $76 \%$. Apabila 
dibandingkan dengan hasil pretes I, terdapat peningkatan nilai rata-rata kelas sebesar 20,40 dan peningkatan prosestase ketuntasan belajar sebesar $48 \%$.

\section{Siklus II}

\section{Aktivitas Belajar}

Prosentase aktivitas siswa secara keseluruhan meningkat dari pertemuan sebelumnya yaitu $68 \%$ menjadi $72 \%$. Peningkatannya sebesar $4 \%$. Pada pertemuan ini, yang bekerjasama sebanyak 10 kelompok siswa $(62,5 \%)$, bertanya 6 kelompok siswa (37,5\%), yang menguasai teknik animasi sederhana sebanyak 12 kelompok siswa (75\%). dan yang menjawab soal uji kompetensi diatas KKM sebanyak 9 kelompok siswa (56\%).

Hasil yang diperoleh dari lembar observasi bahwa yang bekerjasama yaitu sebanyak 16 kelompok siswa (100\%), yang bertanya dan 3 kelompok siswa (18 $\%$ ), yang menguasai teknik animasi sebanyak 15 kelompok siswa (93\%) dan yang menjawab soal uji kompetensi diatas KKM sebanyak14 kelompok siswa (87 \%). Prosentase aktivitas kelas keseluruhannya mencapai $88 \%$.

\section{Hasil Belajar}

Hasil yang diperoleh dari pretes II memberikan skor nilai rata-rata kelas sebesar 50,60 dan ketuntasan belajar siswa mencapai $48 \%$, yaitu 12 orang siswa yang sudah tuntas dari 25 orang siswa. Setelah pembelajaran dilakukan sebanyak 2 kali pertemuan, diperoleh hasil dari postes II dengan ketuntasan belajar sebesar $84 \%$ dan nilai rata - rata sebesar 72,00 . Kenaikan dari pretes ke postes sebesar $36 \%$ dan kenaikan nilai rata -ratanya sebesar 21,40 .

\section{Motivasi}

Dari angket yang diberikan pada siswa diantaranya ditanyakan merasa senang kegiatan belajar kimia, belajar kimia dengan meng-gunakan animasi sederhana terasa lebih mudah untuk memahami konsep ikatan pada senyawa 
karbon. Berdasar hasil angket yang diberikan kepada siswa diperoleh hasil siswa yang senang dengan kegiatan belajar Kimia 19 orang siswa setuju (76\%), 5 orang siswa ragu-ragu (20\%) dan 1 orang siswa tidak setuju (4\%), sedangkan belajar dengan diskusi kelompok 23 orang siswa setuju (92\%), 2 orang siswa ragu-ragu (8\%), yang merasa senang belajar dari penjelasan teman 23 orang siswa setuju (92\%), 2 orang siswa ragu-ragu (8\%), yang merasa mudah memahami penjelasan teman 20 orang siswa setuju ( $80 \%), 3$ orang siswa ragu-ragu (12\%), dan 2 orang siswa tidak setuju ( $8 \%$ ), dan yang berpendapat perlu dikembangkan sebanyak 21 orang siswa setuju (84\%), sedangkan 4 orang siswa ragu-ragu (16 $\%)$.

\section{Refleksi}

Prosentase Aktivitas Kelas

\begin{tabular}{|c|c|c|c|c|c|}
\hline Siklus & & \multicolumn{2}{|c|}{ Siklus I } & \multicolumn{2}{|c|}{ Siklus I } \\
\hline Pertemuan & & 1 & 2 & 1 & 2 \\
\hline $\begin{array}{l}\text { Persen Aktivitas } \\
(\%)\end{array}$ & Kelas & 36 & 68 & 72 & 88 \\
\hline
\end{tabular}

Prosentase Ketuntasan Belajar

\begin{tabular}{cccc}
\hline Siklus & Pretes & Postes & Perbedaan \\
\hline I & $28 \%$ & $76 \%$ & $48 \%$ \\
\hline II & $48 \%$ & $84 \%$ & $36 \%$ \\
\hline
\end{tabular}

Skor Nilai Rata-rata Kelas

\begin{tabular}{cccc}
\hline Siklus & $\begin{array}{c}\text { Skor Nilai Rata-rata } \\
\text { pretes }\end{array}$ & $\begin{array}{c}\text { Skor Nilai Rata- } \\
\text { rata Postes }\end{array}$ & Perbedaan \\
\hline I & 44,20 & 64,60 & 20,40 \\
\hline II & 50,60 & 72,00 & 21,40 \\
\hline
\end{tabular}




\section{KESIMPULAN}

Berdasarkan analisis, temuan dan pem-bahasan yang diuraikan pada Bab IV tentang proses pembelajaran pada konsep senyawa karbon dengan menggunakan animasi sederhan hasil ciptaan peneliti dan model pembelajaran kooperatif tipe SAVI, dapat disimpulkan sebagai berikut :

1. Proses pembelajaran dengan menggunakan model pembelajaran kooperatif tipe SAVI dapat meningkatkan motivasi belajar siswa.

2. Proses pembelajaran dengan model pembelajaran kooperatif tipe SAVI dapat meningkatkan hasil belajar konsep senyawa karbon. Peningkatan hasil belajar dapat dilihat dari ketuntasan belajar siswa. Ternyata di siklus I ada peningkatan ketuntasan belajar sebesar $48 \%$, yaitu dari $28 \%$ menjadi $76 \%$. Dan di siklus II meningkat sebesar $36 \%$, yaitu dari $48 \%$ menjadi 84 $\%$.

\section{REFERENSI}

Dimyati, (2002), Belajar dan Pembelajaran, Jakarta, P.T. Rineka Cipta.

Mendiknas, (2006), Kurikulum Tingkat Satuan Pendidikan (KTSP), JakartaPusat Kurikulum Balitbang Depdiknas.

Muhibin Syah, (2003), Psikologi Belajar, Jakarta, PT. RajaGrafindoPersada

W.Gulo (2004), Strategi Belajar Mengajar.Jakarta, PT. Grasindo

Rooyakkers, A. (1984), Mengajar dengan Sukses, Bandung, Gramedia.

Sudjana, N. (1989), Cara Belajar Siswa Aktif dalam Proses Belajar Mengajar, Bandung, Sinar Baru.

Suhardjono, Azis Hoesein, dkk. (1996) Pedoman Penyusunan Karya Ilmiahdi Bidang Pendidikan dan Angka Kredit Pengembangan Profesi

Widyaiswara. Jakarta:Depdikbud, Dikdasmen. 
Suhardjono, (2006), Laporan Penelitian Sebagai KTI, makalah padapelatihan peningkatan mutu guru dalam pengembangan profesi diPusdiklat Diknas Sawangan, Jakarta, Februari 2006.

Suharsimi Arikunto, Suhardjono dan Supardi (2006), Penelitian TindakanKelas, Jakarta, Bumi Aksara.

Sujadi, Eko. 2017. Penerapan Pendidikan Karakter Cerdas Format Kelompok Untuk Meningkatkan Nilai Kejujuran Mahasiswa Bimbingan Konseling Islam (BKI) Institut Agama Islam Negeri (IAIN) Kerinci. Tarbawi : Jurnal Ilmu Pendidikan, 13(1): 97-108.

Sujadi, Eko., \& Wahab, Martunus. 2018. Strategi Coping Korban Bullying. Tarbawi : Jurnal Ilmu Pendidikan, 13(2): 21-32.

Hayati, Isnaria., \& Sujadi, Eko. 2018. Perbedaan Keterampilan Belajar Antara Siswa IPA Dan IPS. Tarbawi: Jurnal Ilmu Pendidikan, 14 (1): 1-10. doi:10.32939/tarbawi.v14i1.250 